RESEARCH ARTICLE

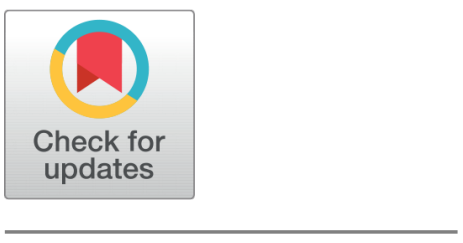

open acCess

Received: 08.02.2021

Accepted: 20.05.2021

Published: 03.07.2021

Citation: Mujumdar MS, Prabhu SG (2021) Study of Telecom Industry Ombudsman and its Regulatory Relevance for Customer Satisfaction. Indian Journal of Science and Technology 14(23): 1929-1943. https ://doi.org/10.17485/IJST/v14i23.255

* Corresponding author.

mujumdarmugdha@gmail.com

Funding: None

Competing Interests: None

Copyright: @ 2021 Mujumdar \& Prabhu. This is an open access article distributed under the terms of the Creative Commons

Attribution License, which permits unrestricted use, distribution, and reproduction in any medium, provided the original author and source are credited.

Published By Indian Society for Education and Environment (iSee)

ISSN

Print: 0974-6846

Electronic: 0974-5645

\section{Study of Telecom Industry Ombudsman and its Regulatory Relevance for Customer Satisfaction}

\author{
Mugdha S Mujumdar ${ }^{1 *}$, Sandeep G Prabhu ${ }^{2}$ \\ 1 Research Scholar, Symbiosis International University, Pune, India \\ 2 Associate Professor, Telecom Department, Symbiosis University, Pune, India
}

\section{Abstract}

Purpose: To study, analyse and compare telecom ombudsman functioning in Australia, the United Kingdom (UK), the United States of America (USA), in context of proposed telecom ombudsman in India. Methods: The study is both explanatory and analytical. Here, Qualitative Analysis is used for analysing primary and secondary data from last four years till 2019-20. Findings: There are rooted norms for how an Ombudsman's functioning runs and how it fits the regulatory/judicial framework. This research study highlights the functioning of an ombudsman in different countries. It also analyses primary data collected through an online questionnaire from Australia, the USA, and India. Also, it examines that the customer satisfaction is higher in markets where there is telecom ombudsman/alternate dispute resolution mechanism. Primary data analysis stresses that countries with telecom ombudsmen prove to be particularly useful in customer experience; however, India, despite being the second-largest telecom market, lacks customer satisfaction in telecom, and highlights the need to revisit some regulatory changes. Only around $8 \%$ of telecom consumers who made a complaint were satisfied with the overall experience. Scope of the Study: This study will be useful for regulators and policymakers of different countries, telecom consumers, public policymakers and think tanks. Novelty: This study proves importance of telecom ombudsman for having transparent grievance handling systems and higher customer satisfaction.

Keywords: Grievance Redressal; telecom regulations; telecom ombudsman; telecom policies; dispute resolution; ADR

\section{Introduction}

There are countries like Australia, the UK who have well-established dispute resolution systems along with ADRs/telecom ombudsman. The study of these systems in context with upcoming Indian telecom ombudsman remains critical. In the dispute resolution space, it is essential to understand systems and exercise those systems to satisfy consumer grievances. It is observed that conflicting scenarios/understanding give birth to "dispute" and hence, there is an immense need for third-party for resolving disputes. 
The mediator roles have developed for dispute resolution on different personal and institutional levels. Dispute resolution is an ongoing process, and it requires continuous fine-tuning to adapt to a changing environment. The adjudication decision-making process falls under the formal methods as judgment is in the window of laws by courts and regulators. Arbitration, negotiation, and mediation are informal processes of dispute resolution and falls under Alternate Dispute Resolution (ADR) method, each having its pros and cons separately. Adjudication, arbitration, mediation, negotiation are prime processes of dispute resolution. Adjudication is a necessary process, while other arbitration, talk, and reconciliation are optional processes. When they are blended, they are called hybrid dispute resolution processes. Hybrid methods showcase the fine-tuning of primary processes. Hybrid approaches are effective in saving time and cost, reducing work pressure on courts. Businesses also use online dispute resolution processes, which are more efficient and less expensive.

Ury et al. (1998) explain the interest-based, rights-based, power-based point of view. Interest-based resolution is a conflict resolution strategy that respects individual differences of approaches and is applied when both parties have a common interest in resolving a dispute. It applies to community disputes. Third parties that resolve disputes concentrate on the quality of results, and all involving parties are satisfied. The third balancing party can be an Ombudsman or a mediator. Right-based approach insists on frameworks of laws than understanding the satisfaction of parties. There is common practice using criteria by alloying them or independently for dispute resolution. There is fundamental difference in dispute and conflict. Conflict should be redressed in a time-bound manner before it becomes disputed. In addition to Ombudsman, some countries possess industry-oriented entities concentrating on communication and self-regulation. Situations, where no conclusion drawn for service providers, are passed to regulators to find a quick solution. These institutions facilitate consumers' free and useful service for dispute resolution.

\section{Literature Review-Telecom Regulations in different countries}

One of the most discussed and argued areas in the telecom business world is the regulation of telecom. The multi-stakeholder approach in telecom regulation facilitates different views, and contrast approaches. Telecom regulations are evolving hand-inhand with the evolution of the industry. The purpose of this literature review is to understand different regulatory aspects, regulatory practices of different countries as well as dispute resolution processes of different countries.

\subsection{About Finnish Telecom Market}

In a typical telecom market, the churn rate is $10 \%$ to $30 \%$; however, it had reached $50 \%$ in the Finnish market. The balanced scorecard tool which considered high consumer churn and regulations was applied to find resolution. This point of view lends a hand to all stakeholders to calculate the performance of national telecom regulation, and it facilitates common ground to validate telecom regulation's performance in terms of attaining its objectives ${ }^{(1)}$.

\subsection{About Argentina, Chile, Jamaica, the Philippines, and the UK}

This research analyses how political practices interconnected with regulatory practices. Without a favorable regulatory environment, deep-rooted investments will not happen. Privatization and amelioration of regulations are tools to improve the quality of service and for reducing prices. Private investments in the sector differ from country to country, depending on political and social circumstances ${ }^{(2)}$.

\subsection{About European Union}

Study analyses how competition in the telecom and electricity sector is governed and are dissimilarities between two governance. According to this research, there are three types of boosting competition: deregulation competition, regulation of game, and regulation for competition. Competition in telecom and electricity is positive when all have equal and open access to networks. Building any government system for competition or even deregulatory norms needs negotiating with political authorities, which obtrudes bureaucrats and politicians. Boosting competition in the sector is dependent on brewing deregulation, regulation of game, and regulation for the race, which customised for every sub-sector ${ }^{(3)}$.

\subsection{About the US, the UK, France, and Sweden}

The increased involvement of civil society will enhance and refine decision-making, facilitating civil society's well-being. It analyses ways which helped to increase civil society participation in the telecom and electricity sector in the UK, France, and Sweden. The bureaus (of Britain and France), taking for this research study, are comparatively new in terms of regulations, so 
they have little barriers in terms of trials. Organisations in the UK and France have made changes in the norms to increase participation from other stakeholders ${ }^{(4)}$.

\subsection{About Mexico with OECD countries and Latin America}

The Mexican telecom sector is undisciplined and sloppy. Issues include no competition in the market; no translucent system exists with inflated prices and infrastructure development. Mexico's telecom services are considered the most expensive in the $\mathrm{OECD}$ (organisation for economic cooperation and development) group of countries ${ }^{(5)}$.

In the US, every state has different regulatory frameworks for intrastate telephone calls; there was a significant transformation in regulations, while some states were adopting the rate of return regulation though they started using price regulation. Price cap regulation is a more efficient and useful tool for setting incentives, refining efficiency, and reducing costs ${ }^{(6)}$.

\subsection{About British Telecom, UK}

The four main contributors to the sector growth are hardware, communication networks, network management systems, and service content. Growth of the telecom and IT sector also depends upon the pace with which technology changes and new technology gets implemented. Other vital contributors affecting the growth of industry and competition are deregulation and privatisation of the sector ${ }^{(7)}$.

\subsection{About Chinese telecom market}

The privatisation of the Chinese telecom market is considered a slow and steady process that has given rise to a worldwide competitive market structure. Both developed countries like the USA, the UK, Japan, and other developing countries also inherited a competitive market structure. There should be an advisory committee on top of regulatory one to give different suggestions, open forums arrangement for making regulations more and more productive ${ }^{(8)}$.

\subsection{About India}

TRAI was established for regulatory decisions, while the licensing function remained with the Department of Telecom. The Indian telecom market has faced uneven situations in terms of regulations and has ranked exceptionally low compared to other Asian countries. Supreme Court intervention in the $2 \mathrm{G}$ spectrum allocation case and the cancellation of 122 licenses made India's regulatory environment vulnerable. The government encouraged state banks to fund service providers in spectrum bids. One hundred percent FDI is allowed in the sector since 2013; however, the lack of transparency in regulatory circumstances is pulling investors away. Important factors contributing to consumer rights are setting an ombudsman in the regulatory framework. For developing nations like India, effective and efficient reforms are needed to form a clean and unequivocal regulatory environment ${ }^{(9)}$.

\subsection{About Canada}

As competition in Canada's telecom market progresses at a faster pace, regulatory changes in the telecom market are bound to happen. In big organisations, it is difficult to handle a large volume of complaints. Competition brings out reasonable costs, and terms of services are also fair, but individual grievances are not well taken care of. So many countries use the ombudsman mechanism for managing individual complaints. In the old days, telecom processes were amiable and relaxed. Processes were strictly regulated, and executed by monopoly basis. Ombudsman handles and manages individual consumer complaints effectively and quickly for resolving disputes in the sector. Ex- Energy and Water Ombudsman in Victoria in Australia handled and managed almost 49000 cases of disputes; for only 36 cases, Ombudsman's decision was binding as parties did not accept the resolution in time from 1996 to Oct $2003^{(10)}$.

\subsection{About Australian Telecom Industry}

With the Australian telecommunication industry moving from state-supplied monopoly services to the legislated duopoly and then to a deregulated competitive industry. The main aim was to provide the industry with an alternative resolution platform for resolving individual consumer complaints. The TOI was a government-mandated, self-regulated but industry-funded body. There was criticism about the quality and methods of operations and ambiguity during the initial period. Further, it was believed that TIO was more suited for the private sector than the public sector as it would not be part of the legal system of public administrative review ${ }^{(11)}$. 
TIO acts as a viable alternate dispute resolution method for the telecom industry. TIO's performance for handling and managing individual complaints was worth noticing. TIO handled an increased number of complaints very effectively and efficiently. In 2010, 167955 number of complaints which are almost twice the complaints received by TIO in 2007, 85188 number which also impacted ombudsman office which has grown from 100 employees in 2007 to 230 employees in 2010. TIO plays a decisive and active role in handling individual complaints between consumers and telecom service providers ${ }^{(12)}$.

The public sector ombudsman scheme provides an alternative dispute resolution framework for resolving consumer grievances. It is partly replacing courts for individual consumer-related matters in the service sectors. The TIO scheme provides unstable situations by making differing rights and remedies from those available in courts. Hence though private Ombudsman is an active industry self-regulating scheme, close monitoring inessential along with standardised quality control assurance mechanism ${ }^{(13)}$.

\section{Dispute Resolution regulations in different countries}

\subsection{Dispute resolution process in European member states}

The liberalisation process in the European telecom sector developed starting from the year 1990 through various directives for liberalisation in the sector and for nurturing healthy competition in the sector. All directives' outcome was a mechanism based on competition, which will mandate member states to adhere to liberalisation norms. This has brought the smooth implementation of regulations. The telecom regulator is the governing body for dispute resolution in EU member states, which says regulatory authority should be independent. Regulators have the choice of not taking specific disputes if it can resolve by some other ADR methods as mediation according to the regulator's opinion. General Agreement on Trade in services (GATS) also has an impact on telecom regulatory norms. This skeleton insists on opening the telecom market to a globally competitive environment ${ }^{(14)}$.

\subsection{Dispute Resolution in France}

Auto rite de Regulation des telecommunication (ART): This entity, formed in January 1997, was responsible for regulating France's telecom sector. France's telecom market was liberalised in 1998. And ART became Auto rite de Regulation des Communications Electroniques et des Posts ARCEP in May 2005.

The main aim of converting ART to ARCEP is to adapt new legal mechanisms, promote competition law, bring it together with sector law, and point out the problems created by the convergence of technologies and coordinate the European market with a systematic approach. The Telecom regulator has the authority to resolve disputes in major four arenas Vis rejection of interconnection, provision of telecom services, shared use of infrastructure, and disputes among nations ${ }^{(14)}$.

\subsection{Dispute Resolution in Germany}

Refinement of telecom norms in Germany telecom market happened in stages from 1989 through policy and regulatory leads. In 1998 establishment of sector-specific entity functioning for policymaking with managerial tasks was done. Parliament keeps an eye on the regulator through the Advisory Council from two houses of the German Parliament. Reg Tp entity is responsible for dispute settlement in Germany. The court can only challenge the decision of the regulator ${ }^{(14)}$.

\subsection{Dispute Resolution in the United States of America}

In the USA, the Federal communications commission (FCC) is the regulatory body that handles and manages policy affairs and is responsible for resolving disputes related to them. The decision, which is concluding and final, is taken by commissioner or panel of commissioners. The FCC body's dispute resolution process is similar to the process of decision-making in regulatory processes. Regulatory processes inclusive of dispute resolution processes are executed in very detailed manner, taking much time and are difficult to execute, although they take care of fairness and transparency in decisions. PUC (Public Utility Commission) functions using similar regulatory processes. Here, the Researcher or author has referred to one paper published in the University of Colorado Law Review; there, he has mentioned how PUC has adopted new processes for resolving disputes. Specifically speaking, he has cited the settlement conference approach of PUC in Texas to resolve informal complaints related to interconnection. The author has also referred to ADR methods used by New York's PUC ${ }^{(14)}$. 


\subsection{Dispute Resolution in Canada}

In Canada, the regulatory entity governing the telecom sector of Canada is the Canadian Radio-Television and Telecom Commission (CRTC). Under Telecom Act1993, CRTC has powers, and its decision is binding and final. Quite different idiosyncratic of CRTC is Industry Committee. The dispute resolution processes are still evolving in Canada, and refinement is on an ongoing basis ${ }^{(14)}$.

\subsection{Dispute Resolution in Denmark}

The National IT and Telecom Agency y (NITA) is responsible for aiding competition in the sector, and protecting consumers' interest in the telecom regulators is the breaking of responsibilities between Ministry and regulator. Ministry governs the regulatory frameworks and regulator the responsibility for implementing it. Ministry governs and deliberately interferes in issues related to regulation through bundle of laws. Situations where no conciliation works out and dispute have not reached the agreement; either party can request NITA for resolution and decide terms and conditions for the interconnection. There are three essential entities except NITA; they are the Telecom Complaint board, the consumer complaint board, and competition compliant tribunal; however, the court has the authority to make final decisions ${ }^{(14)}$.

\subsection{Dispute Resolution in Malaysia}

In Malaysia, the Malaysian Communication and Multimedia Commission (MCMC) established under communication and multimedia Act 1998 have the responsibility of regulations for converging communication and multimedia industries. Consumer protection remains at the centre by the commission. The Malaysian archetype adheres to justice's natural process while investigating disputes and inquiries ${ }^{(14)}$.

\section{About India}

This research study has measured seven clusters of customer groups of seven suggestions of TRAI, and seven factors are which must adhere TRAI's recommendations for consumer protection, mobile number portability (MNP), undesirable commercial communication, complaint redressal system, telecom tariff, quality of customer service and billing related issues ${ }^{(15)}$.

The study analyses the antecedents of customer satisfaction with the Indian mobile industry. The study uses the ASCI model to analyze the antecedents of customer satisfaction in the mobile industry in India. Trust is the factor included in the model to analyse the relationship between customer satisfaction and trust. High customer satisfaction is related to high service quality.

Right strategies are to be crafted by service providers in India to meet customers 'expectations. Customers who tend to be satisfied are not sensitive to price. Satisfied customers have trust and commitment to the mobile service provider. Outcomes of customer satisfaction are the positive word of mouth, increased company image, and reputation, which add a positive dimension and facilitate managers' perspective ${ }^{(16)}$.

Customer-based brand equity (CBBE) in the Indian telecom sector, CBBE is essential in the operation framework of business in building a more reliable brand. There is concentrated competition in the Indian telecom sector as there is hardly product and service differentiation. Customers always seek for viable deals and expect excellent service like network coverage; creative value-added services. $^{(17)}$.

\section{About China}

The next study is in China's context, which reveals that service quality, customer satisfaction, and customer values essential for both manufacturer and service providers. Here, the research study centers the measurement of service quality in the Chinese context by using the SERVQUAL model ${ }^{(18)}$.

\section{Study of Dispute Resolution Mechanisms Mainly Telecom Ombudsman in Selected Countries and Secondary Data Analysis}

\subsection{Australia's Dispute Resolution Mechanism:}

\section{Regulatory Framework in Australia}

- Policymaker- Department of broadband, communication, and digital economy 
- Regulator- Australian Communications and Media Authority (ACMA) is the regulator for broadcasting internet, radio communications, and telecommunications

- Legal Framework- Australian Communications and Media Authority Act 2005

- They are reporting- Reports to the minister of broadband communication and Digital economy.

- Funding- a collection of revenue through broadcasting, radio communication and telecom license fees, spectrum allocation charges through the federal budget

Australian Competition and Consumer Commission: It is an independent commonwealth statutory body, which enforces competition and consumer act 2010 and other legislations.

Australian Communications Consumer Action Network: This is Australia's peak communications consumer organisation representing individuals, small businesses, and non-profit groups.

Complaint resolutionFramework

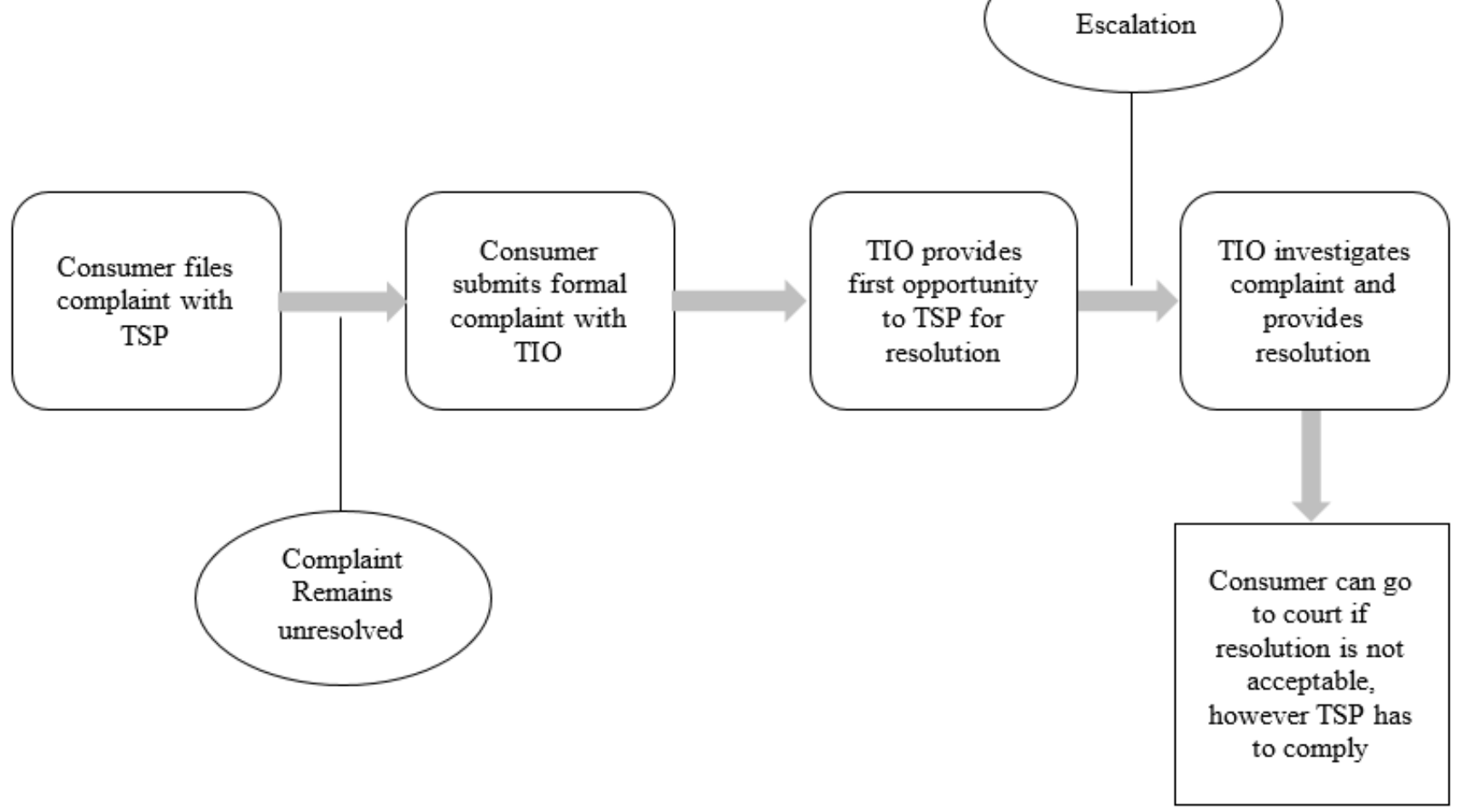

Fig 1. Complaint process in Australia

The Australian Communications and Media Authority Act 2005 (ACMA), the Australian Competition and Consumer Commission (ACCC), the Telecom Industry Ombudsman (TIO), which is funded by the industry itself, and the Australian Communication Industry Forum (ACIF) are the four bodies which are central to the Australian telecom industry.

TIO was established in 1993 to provide fair, independent, and accessible alternate dispute resolution services for residential and small business consumers. This service is free, and any consumer with unresolved complaints on mobile or internet services can approach TIO. TIO's scope of service pertains to 3 main points

1. Dealing with individual and systemic complaints

2. Promoting fair and effective resolution of complaints and

3. Providing information and analysis to government and industry.

Australian telecom industry believes in resolving problems with negotiation tools before they become furious in the future. At the first stage, the problems are seen and analysed, the second stage is where the measuring of conflicts is conducted, the third stage of deciding about the issue by ACCC. Other ways of dispute resolution are forwarding the disputes to the expert committee or giving parties for negotiation. 


\subsubsection{Key Data Points and Analysis}

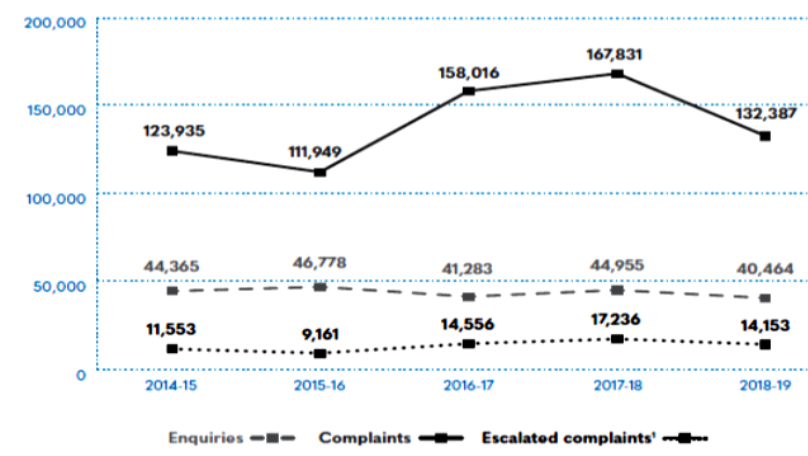

Fig 2. No of complaints received by TIO over the past five years (complaints trend)

Table 1. Complaints by services types

\begin{tabular}{lllll}
\hline & $2015-16$ & $2016-17$ & $2017-18$ & $2018-19$ \\
\hline Mobile & $36.6 \%$ & $33 \%$ & $30.6 \%$ & $30.3 \%$ \\
Internet & $34.6 \%$ & $40.4 \%$ & $27.8 \%$ & $32.6 \%$ \\
Landline & $28.8 \%$ & $26.5 \%$ & $11.2 \%$ & $13.0 \%$ \\
Multiple $^{*}$ & - & - & $29.7 \%$ & $23.2 \%$ \\
\hline
\end{tabular}

${ }^{*}$ complaints about more than one service

(Source: TIO Regulatory Reports)

Who complains: Individual customers always account for more than $85 \%$ of total complaints

Table 2. Types of complainants

\begin{tabular}{ll}
\hline Individual.residential consumers & $\sim 85-90 \%$ \\
\hline Small businesses & $11-14 \%$ \\
Non-profit groups & Less than $0.3 \%$ \\
\hline
\end{tabular}

The top 3 complaints categories across internet, mobile, landline services were

1. Customer service

2. Payment for service and

3. Delivery of service

\subsubsection{The complaint outcome (for escalated complaint)}

Around $75 \%$ of closed complaints have financial Outcome by way of billing adjustment, followed by waiver/reduction of fees, dues.

Table 3. Complaints closure time

\begin{tabular}{lll}
\hline & $2017-18$ & $2018-19$ \\
\hline Escalated complaints & 18088 & 13415 \\
Closed within 60 days & $77 \%$ & $47 \%$ \\
Closed within 120 days & $94 \%$ & $85 \%$ \\
\hline
\end{tabular}

Telecom Industry Ombudsman aims to facilitate impartial, independent, and transparent disputes for individual Australian telecom consumers. The board of TIO, along with the government, continuously reviews the complaints and performance of TIO.TIO always disseminates no complaints, resolution time, and top complaint categories to government and public and 
corrective steps taken by TIO to overcome an upward trend or increase closure time. Focusing on effectiveness, fair, translucent service of dispute resolution with integrity intact is the main characteristic of the Ombudsman service in Australia.

In the year 2018-19, for the telecom industry, the Ombudsman had designed and developed a new strategy. The increasing complaint trend was tackled by the Telecom Industry Ombudsman by increasing staff members and making structural changes in the framework. Board of Ombudsmen has developed engagement with other stakeholders, making sure the privacy of data and simplicity in accessing the service. Further, TIO focused on improving its capabilities and engagement with service providers to counter complex complaints and reduce closure times, which shoot up in 2018-19.

\subsection{Dispute Resolution in Telecom in the UK}

\section{Regulatory Framework in the UK}

- Industry Regulator- OFCOM (Office of Communication)

- Policymaker- Department of Business, Enterprise, and Regulatory Reform.

- Legal Framework- Office of Communication Act 2002

- Reporting Obligation

- Department of Business, Enterprise, and Regulatory Reform/Parliament

- Source of Funding-Department of Trade and Industry for Spectrum Management, TV/Broadcast License Fees

In the $\mathrm{UK}$, the regulation of the telecom sector is the core responsibility of the OFCOM. OFCOM protects consumers regarding terms of price, service quality, and value for money.

Two agencies do the vital role of dispute resolution promptly in the sector. Office of telecom ombudsman (OTELO, now known as Ombudsman Services) and communications and internet services adjudication scheme (CISAS) is funded by industry. They are responsible for fair and swift service to customers. OTEL's decision is binding on the complaint parties 'and the service provider. OTELO has the authority to give compensation of around 5000 Euros.

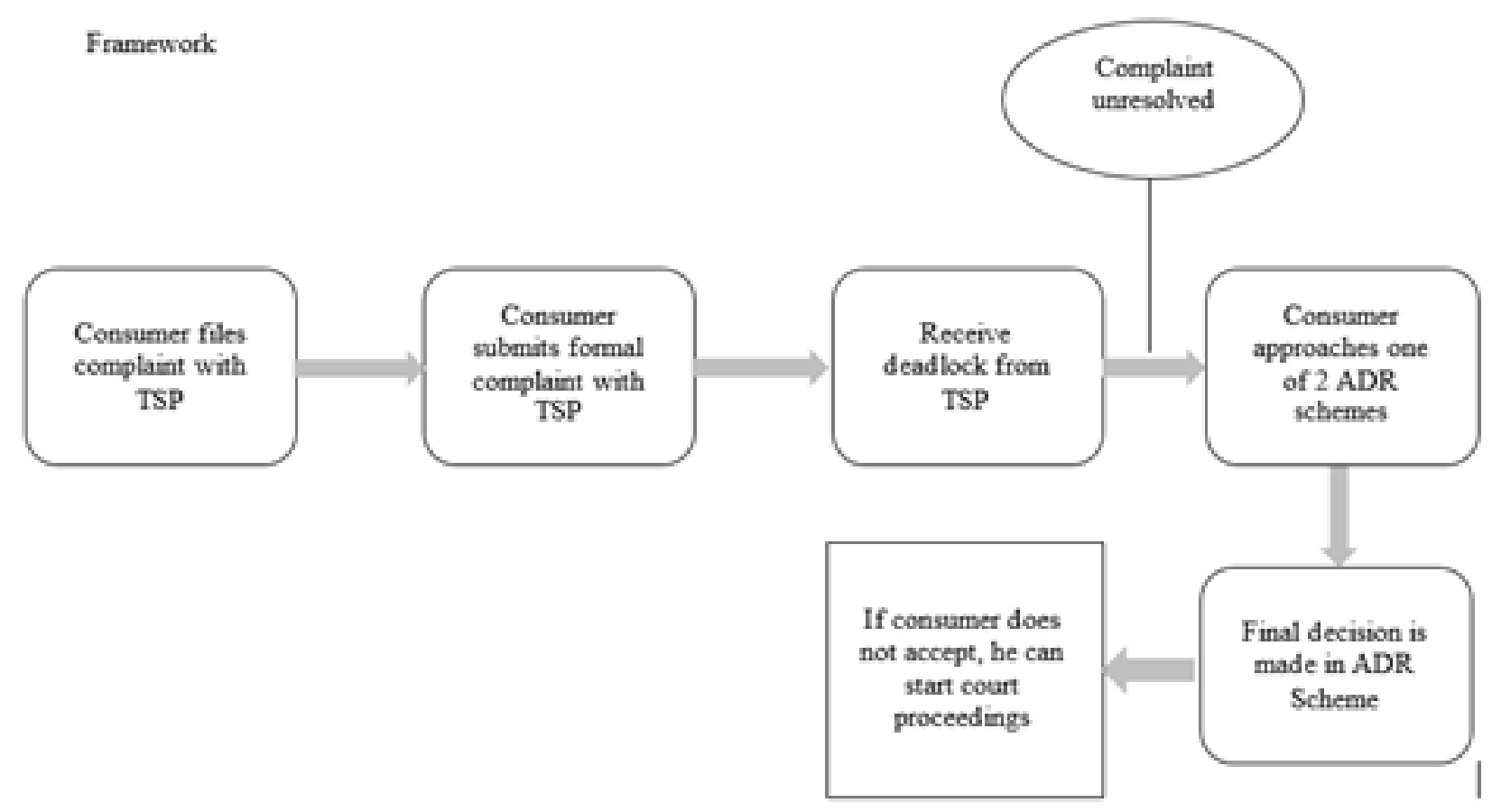

Fig 3. The complaint process inthe UK 


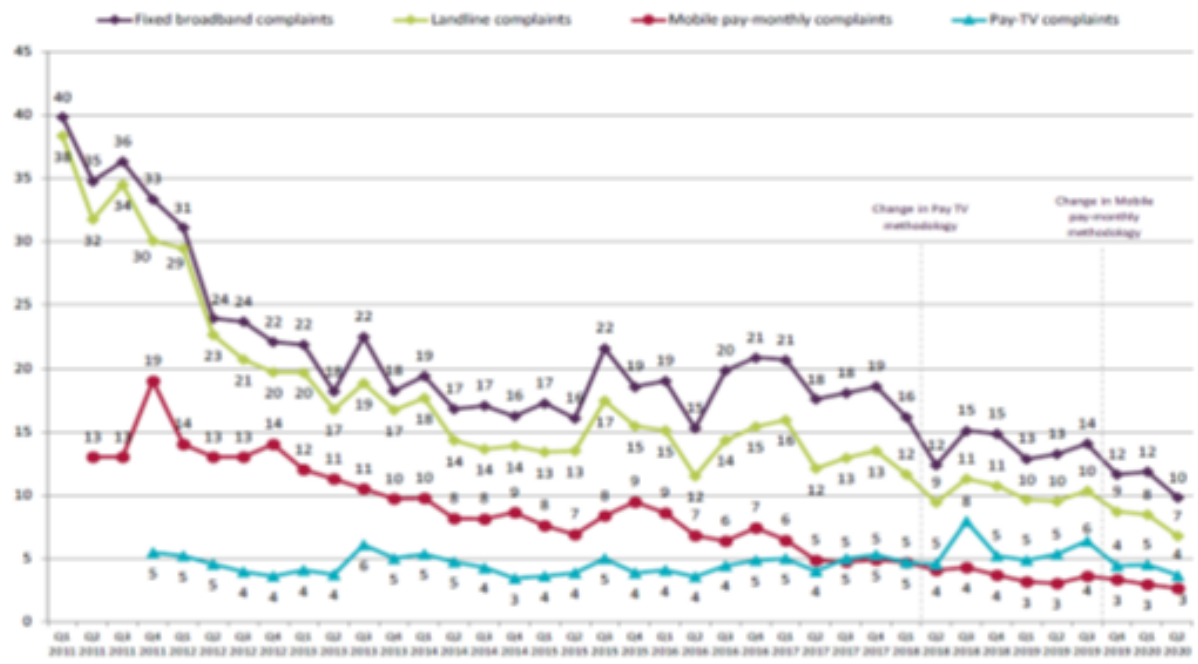

Fig 4. Volume of complaints persector per 100,000 connections/customers

\subsubsection{Key Data Points and Analysis}

As seen from the above graph, the volume of complaints about all sectors/categories have gradually comedown over the last eight years.

\subsubsection{Complaints data}

Table 4. UK complaints data summary

\begin{tabular}{lll}
\hline Total contacts/complaints & 78085 & 62233 \\
\hline Complaints resolved & 41751 & 21251 \\
\% of complaints outside the terms of reference & $51 \%$ & $60 \%$ \\
Complaints resolved under six weeks & $73 \%$ & $98 \%$ \\
Complaints resolved under eight weeks & $78 \%$ & $99 \%$ \\
\hline
\end{tabular}

Table 5. Top Complaints types

\begin{tabular}{lll}
\hline & CY2017 & CY2018 \\
\hline Billing & $34 \%$ & $33 \%$ \\
Service Quality & $26 \%$ & $23 \%$ \\
Contract Issuer & $14 \%$ & $15 \%$ \\
\hline
\end{tabular}

The OFCOM publishes provider and sector-specific data as well which makes the consumer aware of the complaint. Scenarios of providers and help them for making informed decisions. It augurs well with OFCOM's primary responsibility of protecting consumer interests. Ofcom insists on facilitating fair, swift, simple, and translucent solution for resolution of disputes.

\subsubsection{Overall consumer satisfaction}

Table 6. Customer satisfaction details

\begin{tabular}{ll}
\hline Year & \% customer satisfaction \\
\hline 2016 & 63 \\
2017 & 71 \\
2018 & 72 \\
\hline
\end{tabular}


In 2018, it was changing year for complaint redressal of telecom sectoring the UK, as they launched a new case management system which improved customer experience.

\subsection{Dispute Resolution in Telecom in the USA}

\section{Regulatory framework}

- USA Act: USA Telecommunications Act, 1934 (USA Act) governs telecom services in the USA and provides national framework and authority to FCC to issue regulations.

- Industry regulator: The Federal Communications Commission (FCC) regulates interstate and international communications by radio, television, wire, satellite, and Cable. The FCC is responsible for enforcing the USA Act and its own regulations.

- Regulatory fees collected by the agency funds the FCC. The complaint service of FCC is free for consumers.

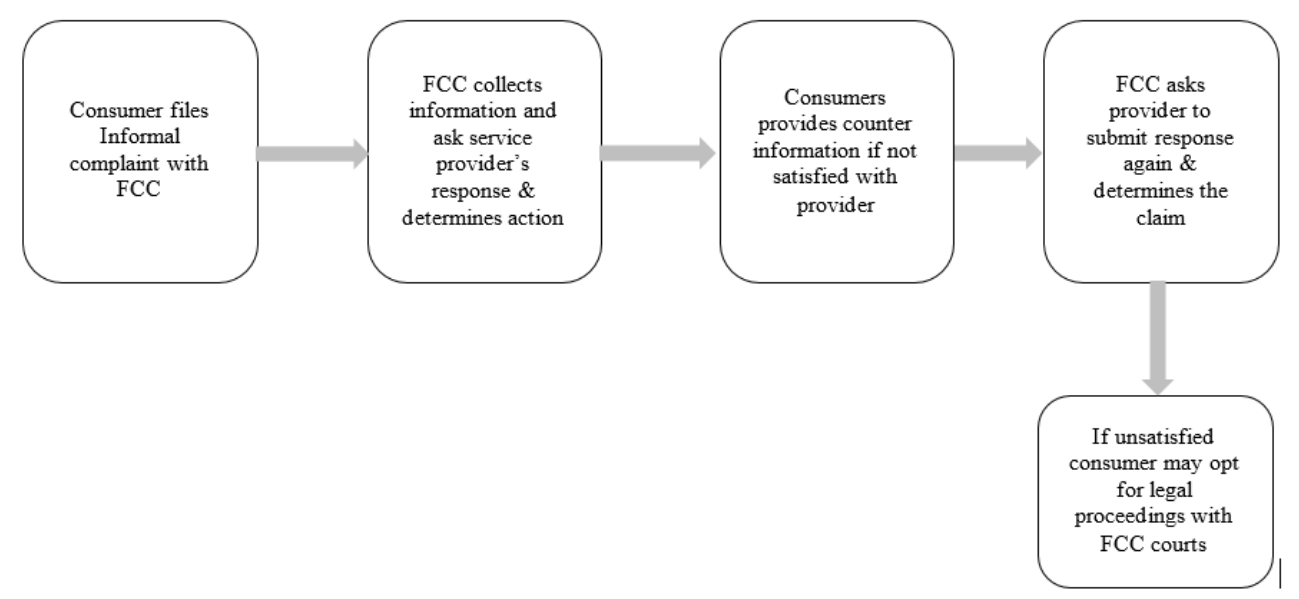

Fig 5. Complaint Resolution Process in the USA

The FCC notifies the company identified in the complaint once it receives all data from consumers. Once a response is received from the provider, the FCC determines whether it is enough to close the complaint.

\subsubsection{Key Data Points}

Service-wise consumer complaints from Jan 1, 2018, to till date:

\begin{tabular}{lc}
\multicolumn{3}{l}{ Table 7. USA complaint data } \\
\hline $\begin{array}{l}\text { Total } \\
\sim 295870\end{array}$ & Complaints: \\
\hline Phone & $79 \%$ \\
TV & $10 \%$ \\
Internet & $9 \%$ \\
Radio \& Others & $2 \%$ \\
\hline
\end{tabular}

\subsection{Current individual Consumer Dispute Resolution Process in Indian telecom}

Fast-changing technology and fierce competition shape up the regulatory norms. The present policies are not enough to manage disputes in the sector.

\section{Regulatory Framework}

Telecom Regulatory Authority of India (TRAI): was established with effect from 1997, by an Act of Parliament, called the Telecom Regulatory Authority of India Act, 1997.Main objective of TRAI is to provide a transparent policy environment which 
promotes a level playing field and facilitates fair competition.

TDSAT was set up to adjudicate any dispute between a licensor and a licensee, between two or more service providers, between a service provider and a group of Consumers. However, TRAI and TDSAT both do not redress individual telecom consumer grievances.

\subsubsection{Current Dispute Resolution Mechanism in India: a 2-tier system}

The first tier is call centre set up by telecom service providers (TSP) and resolves at the service provider's nodal officer if the complaint is unresolved. The second tier is the appellate authority for resolving complaints if the complaint remains unresolved in the first level. There is no ADR currently in India.

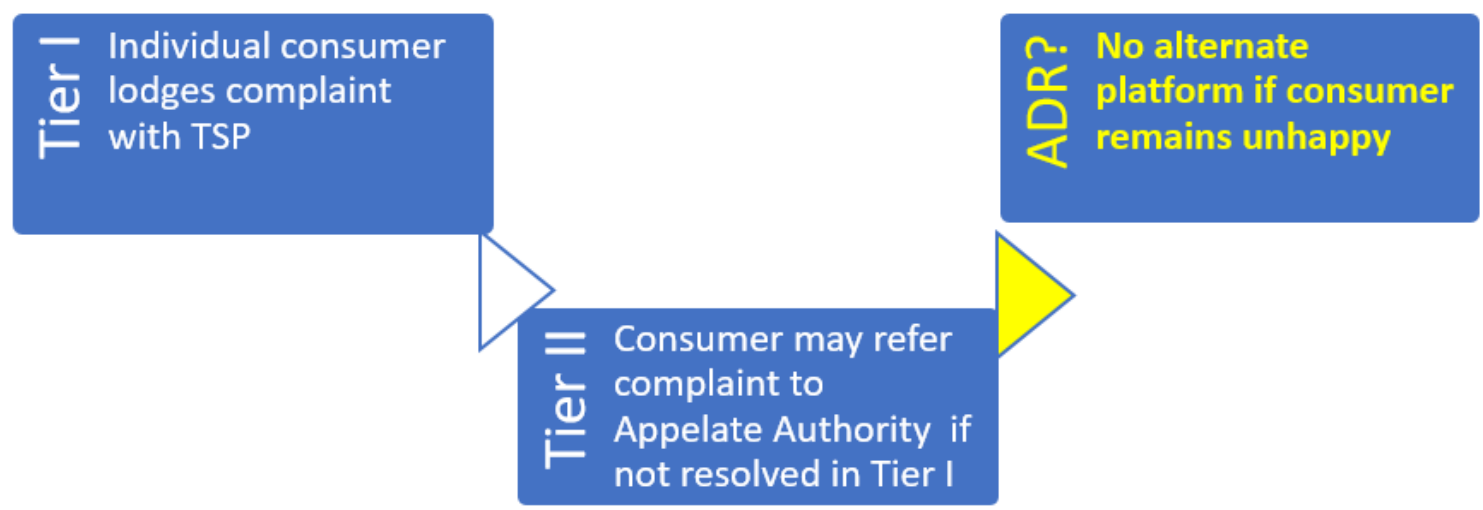

Fig 6. Current complaint process

\subsubsection{Role of TRAl in dispute resolution}

India has agreed to self-regulation by setting up the TSP-led consumer redressal process. Though TRAI doesn't entertain individual complaints, it has framed a number of processes to guard the interest of consumers and made sure quality of Service is made available by telecom service providers (TSPs).TRAI is following with TSPs to improve their performance and has also been striking financial hindrance wherever nonconformity with the benchmarks is seen.

\subsubsection{The Prognosis}

Many customers are not satisfied with their service providers, and there is a significant increase in mobile number portability (MNP) requests. According to data in November 2017, 13 million subscribers changed their service provider. According to below data provided by TRAI maximum number of MNP requests has come from Gujarat, and secondly from Maharashtra. First MNP was introduced in Haryana state in 2017, which gave around 7.63 million subscribers to port their subscribers.

Table 8. Mobile number portability complaints data (till Nov 2017)

\begin{tabular}{llll}
\hline State & Complaints & State & Complaints \\
\hline Delhi & 6,85009 & Andhra Pradesh & 9,55160 \\
Gujarat & 1297951 & Assam & 36252 \\
Himachal Pradesh & 57298 & Bihar & 298073 \\
Haryana & 762512 & Karnataka & 983375 \\
Jammu\& Kashmir & 2942 & Kerala & 539429 \\
Maharashtra & 1032593 & Kolkata & 321450 \\
Mumbai & 477459 & Madhya Pradesh & 840001 \\
Punjab & 598487 & North East & 9688 \\
\hline
\end{tabular}


Table 9. Direct complaints received by DoT \& TRAI

\begin{tabular}{llll}
\hline \multirow{2}{*}{ Year } & \multicolumn{2}{l}{ No. of complaints received } & Total \\
\cline { 2 - 3 } & DoT & TRAI & 57363 \\
2013 & 37202 & 20161 & 72651 \\
2014 & 52265 & 20386 & 87257 \\
2015 & 63964 & 23293 & 38702 \\
\hline
\end{tabular}

(Data Source: TRAI)

Dissatisfied consumers raising complaints with TRAI/DoT were shown in the table alongside. Considering more time consumed for redressal of consumers' complaints by TSPs and low costs involved in redressal function and large no of direct complaints to DoT and TRAI indicate inadequacy in the resolution system.

Table 10. DTH complaints received by TRAI and Ministry

\begin{tabular}{lll}
\hline Year & No. of complaints received by Ministry of Information and Broadcasting & No of complaints received by TRAI \\
\hline 2015 & 448 & 354 \\
2016 & 651 & 562 \\
2017 & 672 & 418 \\
2018 & $151($ till 02.04 .2018$)$ & $147($ till 26.03.2018) \\
Total & 1922 & 1481 \\
\hline
\end{tabular}

(DataSource-https://www.televisionpost.com/mib-trai-received-3403-complaints-against-private-dth-ops-in-three-years-irani/)

The above data shows the number of complaints received by TRAI and the Ministry of Information and Broadcasting from 2015 to 2018 from DTH customers. Ministry of Information and Broadcasting and TRAI received total 3403 complaints against private Direct to Home (D2H) operator in three years till March 2018. After the Ministry receives complaints, they get passed on to respective DTH operators for resolution. The complaints like subscription rate, tariff order, and channel package are forwarded to TRAI for redressal under intimating to this Ministry. The direct complaints to regulatory authorities reveal the below-average status of complaint resolution framework handled by service providers.

\subsection{Indian Telecom Sector Ombudsman: Status}

The DoT has proposed creating independent body ombudsman for the telecom sector to resolve consumer complaints. In March 2018, TRAI has revealed that the Ombudsman has the power to penalise service provider. On May 1, 2018, the Telecom Commission passed the proposal of creating entity ombudsman in the telecom sector. Commission has also agreed to make necessary changes in the TRAI Act that are necessary to implement a new three-tier system for redressal of consumers, including Ombudsman as the third tier.

\subsection{The dispute resolution in telecom section and their role in customer satisfaction and CRM of telecom operator}

Customer relationship management (CRM) has got noteworthy focus post-liberalization as it is a precondition for marketdriven and customer-centric services. CRM to be efficient, backend course of actions for grievance redressal (of unsatisfied customers) are essential. Customer satisfaction has tremendous importance and customer retention is main need of telecom service provider.TRAI is attempting to produce awareness among consumers. So, an implementation of well-resourced CRM and grievance redressal policy will help TSP's to improve satisfaction and trustworthiness of customers.

\section{Primary Data Analysis of Australia, the USA, and India}

Overall, 76 responses were collected through online questionnaires from respondents from Australia, the USA, and India. 


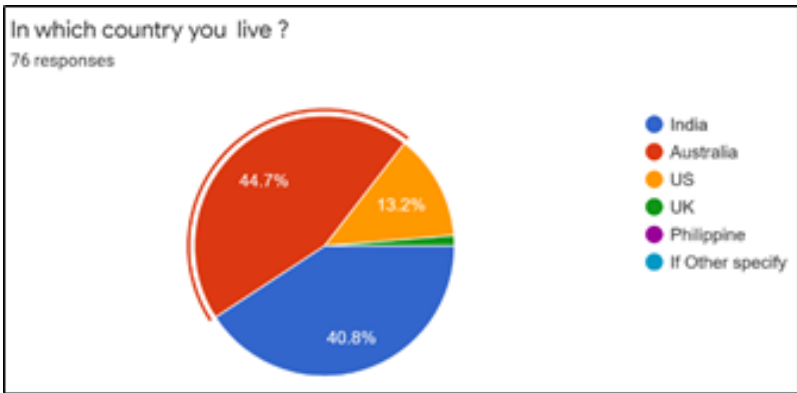

Fig 7.

\subsection{The Analysis from Australia and the USA}

It reveals that countries having telecom ombudsman is facing fewer issues, and telecom consumers are satisfied with TSP complaint resolution as well as the service they are getting from their operator. So overall Analysis from primary data collected reveals the following facts:

- In India where telecom ombudsman or any third party for complaint resolution is not present, telecom consumer satisfaction about services is low.

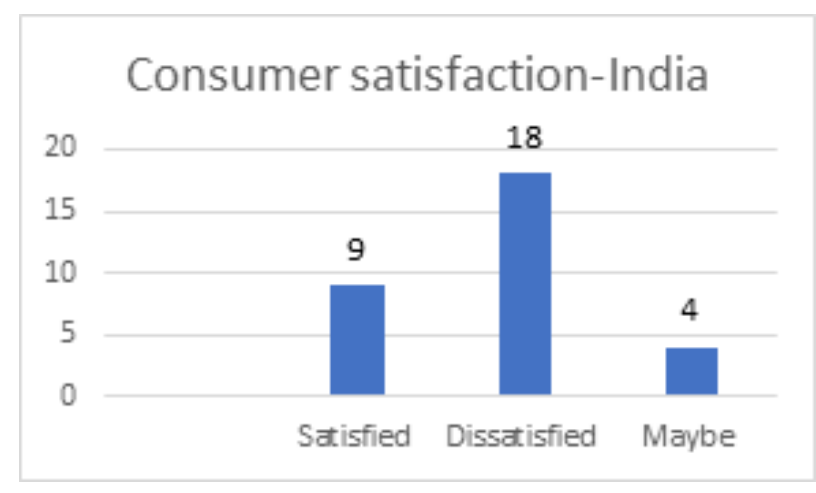

Fig 8. Consumer Satisfaction-India

- Australia:

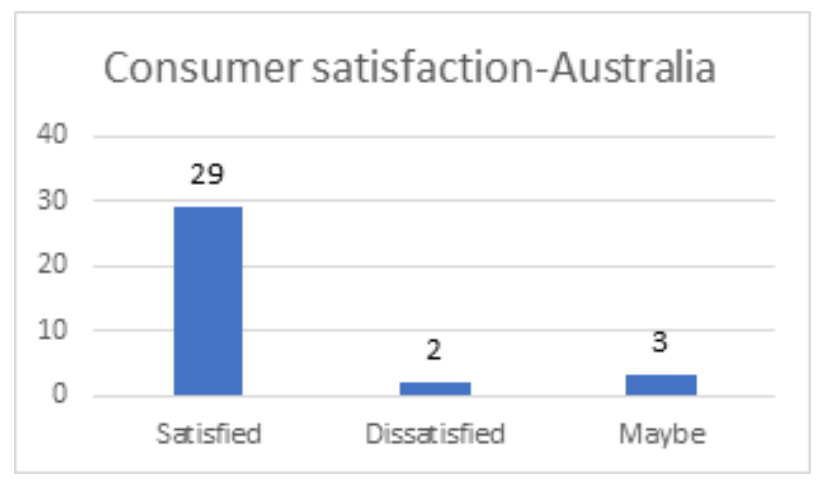

Fig 9. Consumer Satisfaction-Australia 
- United States of America (USA)

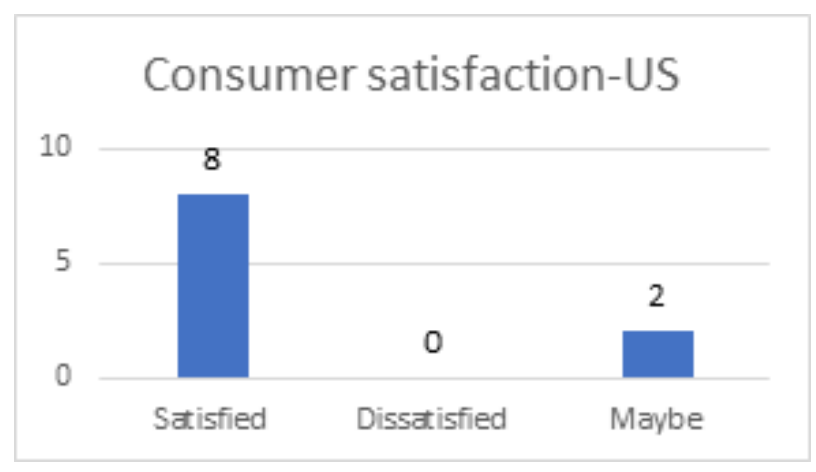

Fig 10. Consumer satisfaction-US

- Most telecom Indian consumers think that there should be the alternate dispute resolution for resolution of disputes.

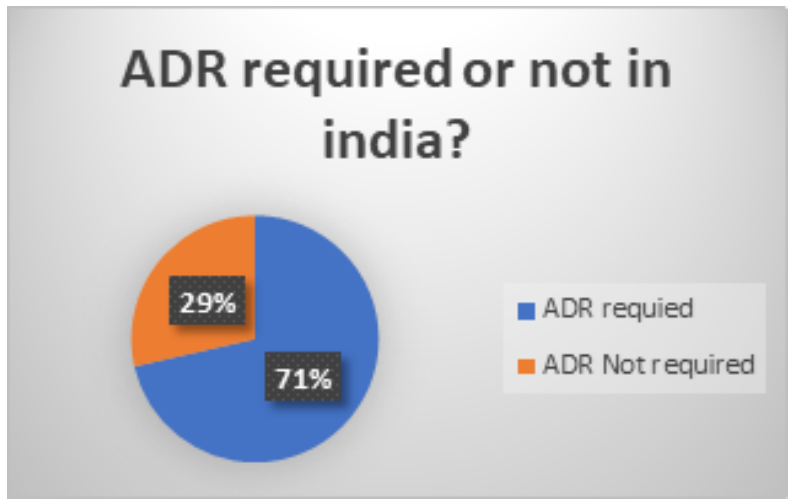

Fig 11.

- Total consumers who made a complaint to their operator and the number of Indian telecom consumers who are satisfied with the operator's complaint resolution (shown in below pie chart), depicts that most consumers are not satisfied with operators to complain about resolution. Only $8 \%$ were satisfied.

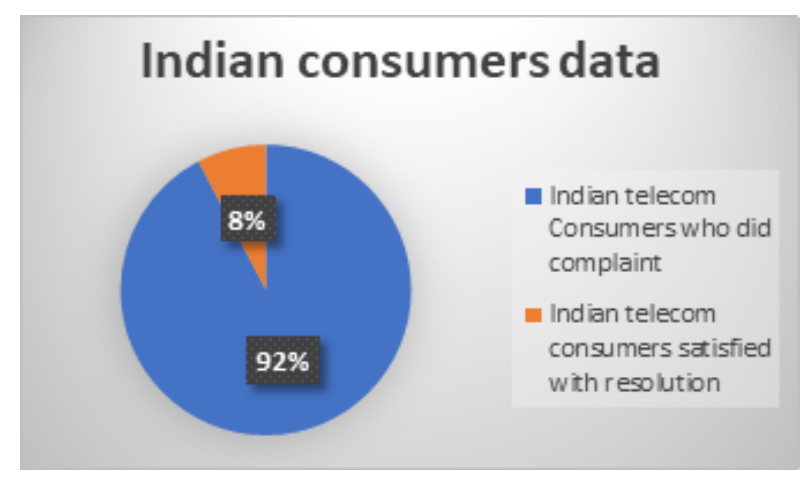

Fig 12. 


\section{Conclusion}

The Analysis helps us conclude:

\section{Demonstrated benefits of ADR in consumer complaint handling process}

A country where Ombudsman scheme exists, the consumer tends to benefit from the presence of independent authority; this enables complaint resolution in low cost, time-bound, and transparent manner. Consumer satisfaction tends to be more in selected countries where there exists an ADR/ telecom Ombudsman.

\section{The regular release of complaints related information and efficiency by /Ombudsman:}

The Ombudsman who work closely with the regulator, periodically (monthly/quarterly/annually) release different data, about the total no. of complaints, types of complainants, region-wise and service provider-wise complaints data, closure time and data and efficiency. Such information helps consumer track the performance of service providers.

\section{India, the second-largest telecom market, lacks ADR/Ombudsman}

As per the existing framework, all the complaint handling is controlled by TSPs and even regulators like TRAI and DoT. Also, the Ministry of broadband has a limited role to play in this. Many instances and data reveal that telecom consumers are not satisfied with the resolution of complaints by service providers. Customer satisfaction in telecom for India is very less compared with developed countries.

\section{References}

1) Vesa J, Kotisaari M. Aimo Maanavilja ,pekka Rauhala RS. 1. Introduction. Finnish Federation for. Communications and Teleinformatics. 2010;1(20). Available from: 10.7788/boehlau.9783412212414.1.

2) Levy B, Spiller P. The Institutional Foundations of Regulatory Commitment : A Comparative Analysis of Telecommunications Regulation Author (s): Brian Levy and Pablo T. Economics, \& Organization. 1994;10(2):201-247. Available from: https://doi.org/10.1093/oxfordjournals.jleo.a036849.

3) Levi-Faur D. The Governance of Competition: The Interplay of Technology, Economics, and Politics in European Union Electricity and Telecom Regimes. vol. 19. Cambridge University Press Stable URL. 2019;p. 175-207. Available from: https://www.jstor.org/stable/4007.

4) Reiss DR. Participation in Governance from a Comparative Perspective: Citizen Involvement in Telecommunications and Electricity in the United Kingdom, France and Sweden. J Disput Resolution. 2009;(2):381-409. Available from: https://heinonline.org/hol-cgi-bin/get_pdf.cgi?handle=hein. journals/jdisres2009\&section $=21$.

5) Bejarano O. The Telecommunications Sector in Mexico : Present and Future in the Context of the. Reform Oscar Bejarano. 2014. Available from: https://scholarship.rice.edu/handle/1911/92491.

6) Grote D. Regulation in the US telecommunication sector and its impact on risk. 2006. Available from: http://regulation.upf.edu/bath-06/6_Grote.pdf.

7) Rica C. Shaping the Competition and Building Competitive Advantage in the Global Telecommunication Industry : The Case of British Telecommunications Plc. 2001. Available from: https://papers.ssrn.com/sol3/papers.cfm?abstract_id=1460529.

8) Iqbal MM. Telecom Industry: Competition, Interconnection Requirements, and the Need for Regulations. The Pakistan Development Review. 1998;37(4):861-871. Available from: https://www.jstor.org/stable/41261087.

9) Hallur GG, Sane VS. Indian telecom regulatory framework in comparison with five countries: structure, role description and funding. Emerald. 2018. Available from: https://dx.doi.org/10.1108/dprg-06-2017-0035. doi:10.1108/dprg-06-2017-0035.

10) Lawford J. Telecommunication Ombudsman for Canada. 2005. Available from: http://www.piac.ca/wp-content/uploads/2014/11/telecom_ombudsman_ for_canada.pdf.

11) Stuhmcke A. The Corporatisation and Privatisation of the Australian Telecommunications Industry: The Role of the Telecommunications Industry Ombudsman. UNSW Law Journal. 1998;21(3):807. Available from: https://heinonline.org/HOL/LandingPage?handle=hein.journals/swales21\&div=56\& $\mathrm{id}=$ \&page $=$.

12) Reform of the Telecommunications Industry Ombudsman. 2012. Available from: https://apo.org.au/node/29373.

13) Li G. Conceptualising the Australian telecommunications industry self-regulation scheme in the context of Australian judicial system and administrative justice. Australian Journal of Telecommunications and the Digital Economy. 2016;4(3):21-43. Available from: https://dx.doi.org/10.18080/ajtde.v4n3.57.

14) Prasad R. Resolving Disputes in Telecommunication. 1st ed. Oxford University Press. . Available from: https://india.oup.com/product/resolving-disputesin-telecommunications-9780198066453.

15) Motwani K. Cluster analysis of Customers in Telecom Industry towards recommendations of TRAI. International Journal of Multidisciplinary. 2018;3085(06):213-221. Available from: https://rrjournals.com/wp-content/uploads/2018/06/213-218_RRIJM18030644.pdf.

16) Balaji MS. Customer Satisfaction with Indian Mobile Services. The IUP Journal of Management Research. 2009;8:52-62. Available from: http: //search.ebscohost.com/login.aspx?direct=true\&db=bth\&AN=44622004\&site=ehost-live.

17) Bedi M, Chopra P. Determinants of Customer Based Brand Equity in Indian Telecommunication Sector. International Journal of Management Studies. 2018;2(5):11. Available from: https://dx.doi.org/10.18843/ijms/v5i2(5)/02.

18) Wang Y, Lo HP, Yang Y. An Integrated Framework for service quality, constomer value, satisfaction: Evidence from China's Telecommunication Industry. Information Systems Frontiers. 2004;6(4):325-365. Available from: https://doi.org/10.1023/B:ISFI.0000046375.72726.67. 